\title{
Combined PGE2 with TNF- $\alpha$ promotes laryngeal carcinoma progression by enhancing GRK2 and TRAF2 interaction
}

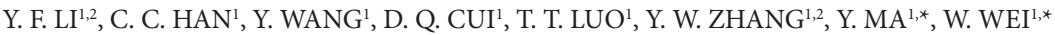 \\ ${ }^{1}$ Institute of Clinical Pharmacology, Anhui Medical University, Key Laboratory of Anti-inflammatory and Immune Medicine, Ministry of Educa- \\ tion, Anhui Collaborative Innovation Center of Anti-inflammatory and Immune Medicine, Hefei, China; ${ }^{2}$ Department of Otorhinolaryngology- \\ Head and Neck Surgery, The First Affiliated Hospital of Anhui Medical University, Hefei, China
}

*Correspondence: wwei@ahmu.edu.cn; mayang_ahmu@126.com

Received May 26, 2019 / Accepted August 21, 2019

\begin{abstract}
TNF- $\alpha$ has been confirmed to promote tumor growth in LSCC. PGE2 expression in LSCC tissues was significantly higher than in tumor-adjacent tissues. In the present work, we aimed to discover the combined role of TNF- $\alpha$ and PGE2 in LSCC progression and its potential mechanisms. TNF- $\alpha$ and PGE2 were quantified by ELISA. TRAF2, MMP-9 and GRK2 expressions were detected by immunohistochemistry and western blot. UM-SCC-11A cell proliferation was tested by CCK-8, and cell migration and invasion were determined by transwell assay. GRK2/TRAF2 interaction was tested by Co-IP. The results showed that TNF- $\alpha$, PGE2, TRAF2, MMP-9 and GRK2 expressions were significantly higher in tumor tissues than in tumor-adjacent tissues. Higher expressions of TRAF2, MMP-9 and GRK2 were associated with poorer prognosis of LSCC. Combined TNF- $\alpha$ with PGE2 promoted UM-SCC-11A cell proliferation, migration and invasion. The interactions of TRAF2 and GRK2, as well as MMP-9 expression, were upregulated in response to TNF- $\alpha$ and PGE2 co-stimulation. In conclusion, we found crosstalk between PGE2 and TNF- $\alpha$ signaling pathways, and the interaction between GRK2 and TRAF2 led to the activation of TNF- $\alpha$-TRAF2-MMP-9 signaling and resulted in the progression of LSCC.
\end{abstract}

Key words: TNF- $\alpha$, PGE2, laryngeal squamous cell carcinoma, GRK2, TRAF2, MMP-9

Laryngeal squamous cell carcinoma (LSCC) is one of the most common head and neck malignancies worldwide with high morbidity and mortality $[1,2]$. Local recurrence and cervical lymph node metastasis are responsible for the treatment failure of LSCC, indicating the clinical significance of researches on the occurrence and metastasis of the disease $[3,4]$. Tumor necrosis factor $\alpha$ (TNF- $\alpha$ ) is the most important cytokine in inflammation-associated tumorigenesis and progression of LSCC $[5,6]$. TNF- $\alpha$ participates in cell proliferation, invasion, metastasis, and cell death via interaction with two cognate receptors, TNFR1 and TNFR2 [7]. After a combination of TNF- $\alpha$ and TNFR, TNF receptor-associated factor 2 (TRAF2), a downstream adaptor molecule, activates NF-kB signaling through forming a multimeric complex with several intracellular proteins. The previous study shows that TNF- $\alpha$ upregulates MMP-9 production via TRAF2-mediated MAPKs and NF- $\mathrm{KB}$ pathways and contributes to bone inflammatory diseases [8]. In addition, TNF- $\alpha$ induces the expressions of adhesion molecules and facilitates the invasion of metastatic tumor cells [9].
Prostaglandin E2 (PGE2), an important pro-inflammatory cytokine, acts on four G-protein coupled receptors (GPCR) EP receptors, involved in several pathological processes, such as pain, fever, angiogenesis and tumor growth [10]. Once the agonist binds, GPCR couples to the heterotrimeric Gs protein, leading to the dissociation of the $\alpha$-subunit and $\beta \gamma$ subunits. Gas activates the release of cyclic AMP (cAMP) and PKA activation, PKA then phosphorylates GRK2, promotes GRK2 translocation to the membrane and phosphorylates the agonist-occupied GPCR, leading to the desensitization and attenuation of GPCR signaling $[11,12]$. In the present study, we detected the levels of TNF- $\alpha$ and PGE2 in LSCC tissues and found both of them significantly increased in the early stage, as well as in the advanced stage compared with tumor-adjacent tissues. Moreover, co-stimulation with TNF- $\alpha$ and PGE2 significantly promoted LSCC cell line UM-SCC-11A proliferation, migration and invasion compared with the single stimulus, indicating that TNF- $\alpha$ and PGE2 can synergistically induce LSCC progression. Further research revealed that GRK2 and TRAF2 interacted with each other under the co-stimulation of TNF- $\alpha$ 
and PGE2 in LSCC tissue. PGE2 facilitates TNF- $\alpha$-induced MMP-9 expression and cell proliferation, migration and invasion in UM-SCC-11A cells.

\section{Patients and methods}

Patients and sample characteristics. In this work, we selected 62 LSCC patients from the department of otolaryngology - head and neck surgery, Anhui Medical University from December 2014 to December 2015 (Table 1). There were 14 losses of follow-up. The follow-up period is 4 years. The tissues we collected by surgery included LSCC tissues and tumor-adjacent tissues. The samples of all patients were classified based on the clinical stage standard of USA joint committee on cancer (AJCC) staging system. This study was approved by the Ethics Committee of Anhui Medical University. The procedure was performed according to the Declaration of Helsinki and Good Clinical Practice. All patient consented to use their images, information and other materials for scientific researches and publications, their names and identifiers were concealed. None of the patients received any preoperative treatment.

Cell culture. LSCC cell line UM-SCC-11A (University of Michigan, USA) was maintained in RPMI-1640 (Gibco, USA) and supplemented with 10\% FBS (Clark, USA) and penicillin-streptomycin. Cells were cultured at $37^{\circ} \mathrm{C}$ in a $5 \%$ $\mathrm{CO}_{2}$ incubator with humidified air.

Immunohistochemistry. Paraffined LSCC specimens were sliced into $5 \mu \mathrm{m}$ thick sections and were deparaffinized in xylene and rehydrated in ethanol. And 0.5\% Triton X-100 was used to permeate the cells for $30 \mathrm{~min}$. After rinsed in PBS, the sections were heated to boiling point for $10 \mathrm{~min}$ in a microwave oven within citrate buffer at $\mathrm{pH}$ 6.0. Afterward, endogenous peroxidase activity was destroyed by a $15 \mathrm{~min}$ hydrogen peroxide (3\%) incubation. After a rinse in PBS, we incubated the slides with primary GRK2 antibody (sc-562, Santa Cruz, USA), TRAF2 antibody (sc-7187, Santa Cruz, USA) and MMP-9 antibody (Santa Cruz, USA) overnight at $4{ }^{\circ} \mathrm{C}$. Then polymer helper was incubated for $20 \mathrm{~min}$ at $37^{\circ} \mathrm{C}$ after PBS rinse. The slides were then incubated with polyper-

Table 1. Clinical samples from department of otolaryngology - head and neck surgery.

\begin{tabular}{|c|c|c|c|c|c|}
\hline & & \multirow{2}{*}{$\begin{array}{l}\text { I+II } \\
\text { stage }\end{array}$} & \multirow{2}{*}{$\begin{array}{l}\text { III+IV } \\
\text { stage }\end{array}$} & \multicolumn{2}{|c|}{ Follow-up (48 cases) } \\
\hline & & & & $\begin{array}{l}\text { Recurrence Rate } \\
\text { (0-48 months) }\end{array}$ & $\begin{array}{c}\text { Death } \\
(0-48 \text { months })\end{array}$ \\
\hline \multirow{3}{*}{$\begin{array}{l}\text { Glottic } \\
\text { Cancer }\end{array}$} & & & & I+II stage: 5 & I+II stage: 2 \\
\hline & Male & 29 & 6 & III+IV stage: 4 & III+IVstage: 2 \\
\hline & Female & 0 & 0 & 0 & 0 \\
\hline \multirow{2}{*}{$\begin{array}{l}\text { Supraglottic } \\
\text { Cancer }\end{array}$} & Male & 15 & 10 & $\begin{array}{c}\text { I+II stage: } 7 \\
\text { III+IV stage: } 8\end{array}$ & $\begin{array}{c}\text { I+II stage: } 4 \\
\text { III+IV stage: } 7\end{array}$ \\
\hline & Female & 1 & 1 & $\begin{array}{c}\text { I+II stage: } 0 \\
\text { III+IV stage: } 1\end{array}$ & $\begin{array}{c}\text { I+II stage: } 0 \\
\text { III+IV stage: } 1\end{array}$ \\
\hline
\end{tabular}

oxidase - anti-mouse / rabbit IgG proceeded for $30 \mathrm{~min}$ at $37^{\circ} \mathrm{C}$. Finally, the specimens were stained with 3,3'-diaminobenzidine tetrahydrochloride and then counterstained with hematoxylin.

Western blot assay. $\beta$-actin, GRK2, TRAF2 and MMP-9 primary antibodies were obtained from Santa Cruz Biotechnology (CA, USA). H-89 was obtained from BioVision Company (SFO, USA) Clinical samples were lysed with RIPA lysis buffer (Beyotime Biotech, China) and protease inhibitor (Calbiochem, Germany). Protein concentration was determined using BCA kit (Thermo, USA). Secondary antibodies were purchased from Santa Cruz Biotechnology; PGE2 and TNF- $\alpha$ were purchased from Cayman Chemical Company; $25 \mu \mathrm{g}$ of total protein were loaded and separated by $10 \%$ SDS-PAGE. The proteins were transferred onto a PVDF membrane. The membrane was blocked by $10 \%$ non-fat dried milk for one hour at room temperature. Subsequently, the membrane was incubated with primary antibody at $4{ }^{\circ} \mathrm{C}$ overnight. And then the membranes were incubated with horseradish peroxidase-conjugated secondary antibodies after washing with TBST 3 times. All primary antibodies were diluted to 1:1000 and all secondary antibodies were diluted to 1:5000. The immune signaling results were visualized by image Quant Las 4000 mini (Sigma, Germany). The optical densities of protein bands were analyzed by ImageJ Software.

Enzyme linked immunosorbent assay (ELISA). The concentrations of TNF- $\alpha$ and PGE2 from clinical samples were examined using ELISA assay (Formesa biotechnology, China). Tissues were rinsed with ice-cold PBS to thoroughly remove the excess of blood and were weighed before homogenization. $1 \mathrm{~g}$ of tissue was homogenized in $10 \mathrm{ml}$ of PBS on ice, followed by the centrifugation for $10 \mathrm{~min}$ at $1000 \times \mathrm{g}$. The supernatant fluid was collected and stored below $-20^{\circ} \mathrm{C}$. $100 \mu \mathrm{l} /$ well of standard or sample were incubated on a plate for $90 \mathrm{~min}$ at $37^{\circ} \mathrm{C}$. The plate was rinsed 4 times, $100 \mu \mathrm{l}$ of primary antibody solution was added to each well and incubated for $60 \mathrm{~min}$ at $37^{\circ} \mathrm{C}$. Then the plate was rinsed 4 times again, and $100 \mu \mathrm{l}$ of TNF- $\alpha$ or PGE2 conjugate was added into each well for $30 \mathrm{~min}$ incubation at $37^{\circ} \mathrm{C} .100 \mu \mathrm{l}$ of substrate solution were added to each well and incubated for 10-20 $\mathrm{min}$, in dark after 4 rinses. Finally, $100 \mu \mathrm{l}$ of stop solution were added. The optical density of each well was determined within $30 \mathrm{~min}$, using a microplate reader (TECAN GENIOS, Swiss) set to $450 \mathrm{~nm}$.

Cell proliferation determination. Cell counting kit-8 (CCK-8) (DOJINDO, Japan) was used for detecting the UM-SCC-11A cell proliferation. After trypsin treatment, cells were resuspended $\left(1 \times 10^{4}\right.$ cell/pore $)$ in RPMI-1640 with $10 \%$ FBS. UM-SCC-11A cells were cultured for 6 hours in 96-well plate before the pretreatment with different concentrations of PGE2 of PGE2 plus TNF- $\alpha$ for 48 hours. After that, UM-SCC-11A cells were cultured in a humidified atmosphere of $5 \% \mathrm{CO}_{2}$ at $37^{\circ} \mathrm{C}$ for another $48 \mathrm{~h}$. Before the culture termination, CCK- 8 was added to the well for $2 \mathrm{~h}$. 
Cell migration assay. UM-SCC-11A cells were cultured in 24-well plates for $2 \mathrm{~h}$ in a humidified atmosphere of $5 \%$ $\mathrm{CO}_{2}$ at $37^{\circ} \mathrm{C}$. Then UM-SCC-11A cells were rinsed with PBS and activated with PGE2 $(0.5 \mu \mathrm{M})$ or PGE2 $(0.5 \mu \mathrm{M})$ plus TNF- $\alpha(20 \mathrm{ng} / \mathrm{ml})$. After trypsin treatment, the cell suspension $\left(4 \times 10^{4} \mathrm{cell} / \mathrm{ml}\right)$ was prepared in RPMI-1640 with $10 \%$ FBS. Transwell chambers (Corning Costar, USA) were used to detect the migration of cells. $100 \mu \mathrm{l}$ of cell suspension were added to the upper chamber, while $600 \mu \mathrm{l}$ of RPMI-1640 with $20 \%$ FBS were added to the lower chamber. After $12 \mathrm{~h}$ incubation in a humidified atmosphere of $5 \% \mathrm{CO}_{2}$ at $37^{\circ} \mathrm{C}$, we removed the transwell insert from the plate and rubbed off the remaining cells which had not migrated from the top of the membrane with a cotton-tip applicator. The cells that migrated through the membrane filter pores stuck to the lower side of the membrane, hence they were fixed in paraformaldehyde and stained with $1 \%$ hexamethylpararosaniline for $15 \mathrm{~min}$. We captured four fields randomly with a fluorescent microscope (OLYMPUS, Japan) and calculated the number of migrated cells.

Cell invasion assay. UM-SCC-11A cells were cultured in 24-well plates for $2 \mathrm{~h}$ in a humidified atmosphere of $5 \% \mathrm{CO}_{2}$ at $37^{\circ} \mathrm{C}$. Cells were rinsed with PBS and activated with PGE2 $(0.5 \mu \mathrm{M})$ or PGE2 $(0.5 \mu \mathrm{M})$ plus TNF- $\alpha(20 \mathrm{ng} / \mathrm{ml})$. Cells were resuspended $\left(4 \times 10^{4}\right.$ cell $\left./ \mathrm{ml}\right)$ in RPMI-1640 with $10 \%$ FBS. Upper chambers of transwell chambers were coated with $20 \mu \mathrm{l}$ of diluted matrigel (Corning Costar) (1:5) and dried in a $37^{\circ} \mathrm{C}$ incubator to form a thin gel layer. After that, $100 \mu \mathrm{l}$ of cell suspension were added to the upper chamber, while $600 \mu \mathrm{l}$ of RPMI-1640 with 20\% FBS were added to the lower chamber. After a $12 \mathrm{~h}$ incubation in a humidified atmosphere of $5 \% \mathrm{CO}_{2}$ at $37^{\circ} \mathrm{C}$, we removed the transwell insert from the plate and rubbed off the remaining cells which had not invaded through the membrane with a cotton-tip applicator. The cells that invaded through the membrane filter pores stuck to the lower side of the membrane and were fixed in paraformaldehyde and stained with $1 \%$ hexamethylpararosaniline for $15 \mathrm{~min}$.

Co-immunoprecipitation (Co-IP) assay. Total proteins were extracted from clinical samples with RIPA lysis buffer and protease inhibitor. The resulting lysate was precleared by incubation for $2 \mathrm{~h}$ at $4{ }^{\circ} \mathrm{C}$ with of $2 \mu$ of TRAF2/EP 4 primary antibody. After that, $20 \mu$ protein A/G agarose beads (Santa Cruz, USA) were added into the protein samples and samples were gently agitated at $4^{\circ} \mathrm{C}$ overnight. The uncombined proteins were separated by centrifuging at $2000 \mathrm{rpm}$ for $5 \mathrm{~min}$ at $4{ }^{\circ} \mathrm{C}$, and the supernatant was discarded. The protein $\mathrm{A} / \mathrm{G}$ agarose beads were washed with $1 \mathrm{ml}$ of scrubbing solution (PBS:PMSF $=100: 1$ ) by spinning at $2000 \mathrm{rpm}$ for $5 \mathrm{~min}$ at $4{ }^{\circ} \mathrm{C}$ and the supernatant was discarded. The immunoprecipitate was resuspended with $4 \times$ Laemmli sample buffer-RIPA (1:4) and was heated the sample at $100^{\circ} \mathrm{C}$ for $8 \mathrm{~min}$.

Statistical analysis. The data were presented as means \pm standard deviation (SD) and collected from at least three separate experiments in triplicate. All the analyses of variance (one-way ANOVA) (SPSS software products, USA) were used to determine significant differences between groups, and the significance was established at ${ }^{*} \mathrm{p}<0.05,{ }^{* *} \mathrm{p}<0.01$. Statistical figures were generated using GraphPad Prism.

\section{Results}

The levels of TNF- $\alpha$ and PGE2 and the expressions of GRK2, TRAF2 and MMP-9 proteins correlated with the clinicopathological characteristics of LSCC patients. In order to investigate the role of TNF- $\alpha$ and PGE2 signaling in LSCC progress, we examined the levels of TNF- $\alpha$ and PGE2 in clinical samples by ELISA assay. 15 patients were collected, 9 of them were in the early stage, and 6 of them were in the advanced stage. The result showed the levels of TNF- $\alpha$ and PGE2 were both increased in the early and the advanced stages compared with the tumor-adjacent tissues and co-existed in 13 patients $(86.7 \%, n=15)$ of LSCC, but there was no significant difference between the early and the advanced stages in both TNF- $\alpha$ and PGE2 (Figure 1A). Meanwhile, we examined by immunohistochemical (IHC) assay the expressions of TRAF2, MMP-9 and GRK2, which are the key molecules in TNF- $\alpha$ and PGE2 signaling. The expressions of TRAF2, MMP-9 and GRK2 in the LSCC tumor tissues were significantly higher than in tumoradjacent tissues (Figure 1B). In addition, we discovered an association between TRAF2, MMP-9 and GRK2 expression and LSCC clinicopathological characteristics and we set $<\mathrm{P}_{75}$ as a low expression while $\geq \mathrm{P}_{75}$ as a high expression with IHC results. It was observed that the expression level of GRK2 or MMP9 was positively associated with a tumor site, recurrence, TNM stage, lymph node metastasis and differentiation grade, while TRAF2 expression was positively associated with a tumor site, recurrence, TNM stage and lymph node metastasis (Table 2).

Next, we detected the expressions of GRK2, TRAF2 and MMP-9 protein in different stages of LSCC progression by western blot assay. In accordance with the IHC results, these three proteins were increased in LSCC tissues in comparison with the tumor-adjacent tissues. And in the advanced stages, the expression was higher than in the early stages of LSCC tissues (Figures 2A, 2B). We further analyzed the relationship between the expressions of GRK2, TRAF2 and MMP-9 and the originated regions of cancer in different stages of LSCC. The results showed that in early stages, the three proteins expressions in glottic and supraglottic cancer were significantly increased in LSCC tissues than in tumor-adjacent tissues, and we found that the three of them were higher in supraglottis than in glottis in LSCC tissues (Figures 2C, 2D). However, in advanced stages, there were no significant statistical differences in different locations of LSCC tissues (Figures 2E, 2F).

The expressions of GRK2, TRAF2 and MMP-9 correlated with the survival of LSCC patients. To discover the correlation between GRK2/TRAF2/MMP-9 protein expres- 
A

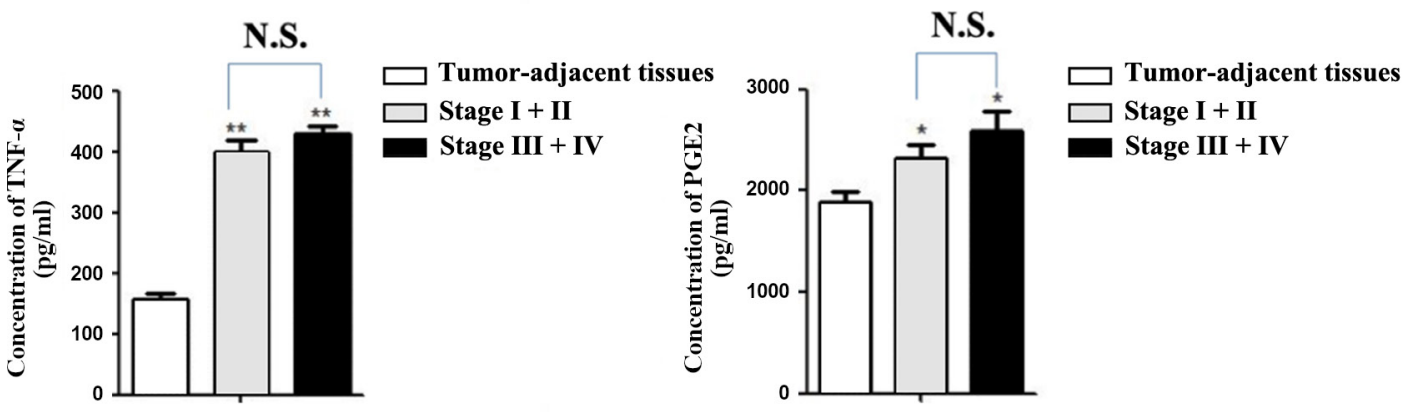

B Tumor-adjacent tissues

LSCC tissues

TRAF2
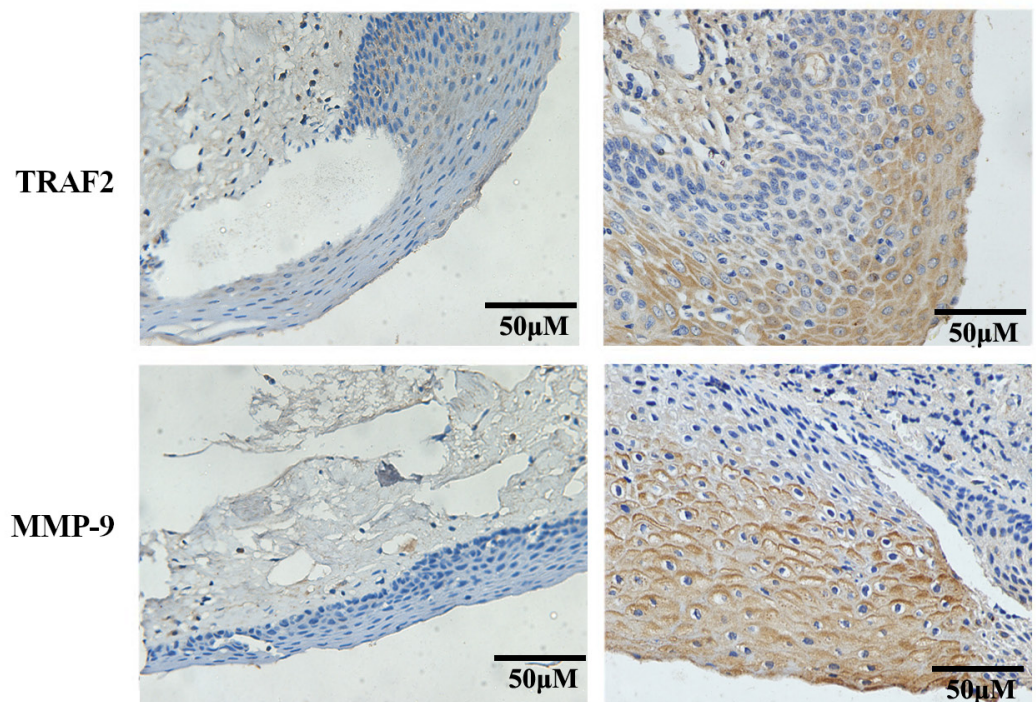

GRK2
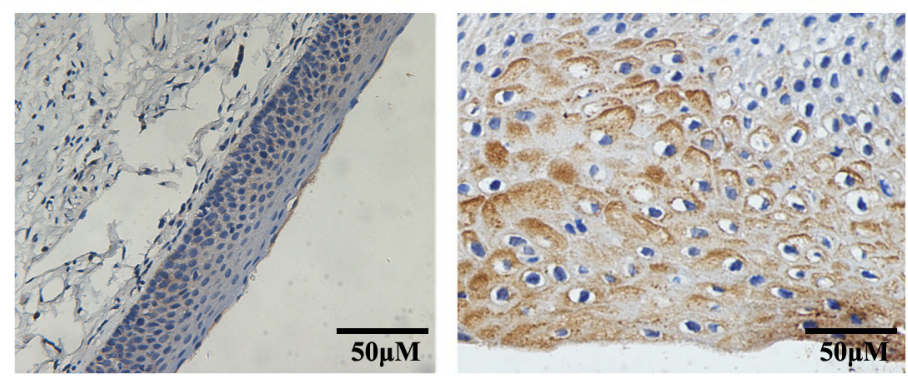

Figure 1. The levels of PGE2/TNF- $\alpha$ and the expressions of TRAF2/MMP-9/GRK2 in LSCC samples. A) The levels of PGE2 and TNF- $\alpha$ in clinical samples were detected by ELISA $(n=15)$; B) Representative images of tumor-adjacent tissues and LSCC tissues immunohistochemically stained with antibodies to TRAF2, MMP-9 and GRK2 $(n=19)$. Results are presented as mean \pm S.D. ${ }^{\star} p<0.05$ versus tumor-adjacent tissues; ${ }^{\star *} p<0.01$ versus tumoradjacent tissues.

sion level and patients' survival, we followed-up the patients for 48 months and their features are shown in Table 1. Among the total 62 patients, 14 patients were lost during followup, and 48 patients remained in the follow-up. From all 48 patients, 25 suffered from recurrence. In 48 patients, 1-year survival rate was $95.8 \%$, 2-year survival rate was $91.7 \%$ and 4 -year survival rate was $66.7 \%$. The results demonstrated that the survival rate of $\geq \mathrm{P}_{75}$ level was lower than that of $<\mathrm{P}_{75}$ level of GRK2/TRAF2/MMP-9 expressions, and the difference was significant (Figure 3). Collectively, these results demon- strated that GRK2, TRAF2 and MMP-9 were upregulated in LSCC tissues and the high expressions of GRK2, TRAF2 and MMP-9 predicted poor prognosis in LSCC, implying that TNF- $\alpha$ and PGE2 signaling act as a tumor activator in LSCC tumorigenesis.

Both separate stimulation and co-stimulation of TNF- $\alpha$ and PGE2 can promote UM-SCC-11A cell proliferation, migration and invasion. The clinical results showed that TNF- $\alpha$ and PGE2 signaling were upregulated in LSCC tumor tissue, so we detected PGE2 level in UM-SCC-11A cells in 
Table 2. Correlation between GRK2/TRAF2/MMP-9 proteins and clinicopathological characteristics of LSCC patients.

\begin{tabular}{|c|c|c|c|c|c|c|c|c|c|c|c|c|}
\hline \multirow{2}{*}{ Characteristics } & \multicolumn{4}{|c|}{ GRK2 } & \multicolumn{4}{|c|}{ TRAF2 } & \multicolumn{4}{|c|}{ MMP-9 } \\
\hline & $<\mathbf{P}_{75}$ & $\geq \mathbf{P}_{75}$ & $\chi^{2}$ & p-value & $<\mathbf{P}_{75}$ & $\geq \mathbf{P}_{75}$ & $\chi^{2}$ & p-value & $<\mathbf{P}_{75}$ & $\geq \mathbf{P}_{75}$ & $\chi^{2}$ & p-value \\
\hline \multicolumn{13}{|l|}{ Gender } \\
\hline Male & 12 & 34 & \multirow{2}{*}{0.696} & \multirow{2}{*}{0.404} & 10 & 36 & \multirow{2}{*}{0.549} & \multirow{2}{*}{0.459} & 12 & 34 & \multirow{2}{*}{0.696} & \multirow{2}{*}{0.404} \\
\hline Female & 0 & 2 & & & 0 & 2 & & & 0 & 2 & & \\
\hline \multicolumn{13}{|l|}{ Age (years) } \\
\hline$<60$ & 3 & 11 & \multirow{2}{*}{0.134} & \multirow{2}{*}{0.714} & 3 & 11 & \multirow{2}{*}{0.004} & \multirow{2}{*}{0.948} & 4 & 10 & \multirow{2}{*}{0.134} & \multirow{2}{*}{0.714} \\
\hline$\geq 60$ & 9 & 25 & & & 7 & 27 & & & 8 & 26 & & \\
\hline \multicolumn{13}{|l|}{ Tumor site } \\
\hline Supraglottic & 0 & 22 & \multirow{2}{*}{13.538} & \multirow{2}{*}{$<0.001^{\star *}$} & 0 & 22 & \multirow{2}{*}{10.688} & \multirow{2}{*}{$0.001^{\star *}$} & 0 & 22 & \multirow{2}{*}{13.538} & \multirow{2}{*}{$<0.001^{* *}$} \\
\hline Glottic & 12 & 14 & & & 10 & 16 & & & 12 & 14 & & \\
\hline \multicolumn{13}{|l|}{ Recurrence } \\
\hline No & 10 & 14 & \multirow{2}{*}{7.111} & \multirow{2}{*}{$0.008^{\star *}$} & 10 & 14 & \multirow{2}{*}{12.632} & \multirow{2}{*}{$<0.001^{\star *}$} & 12 & 12 & \multirow{2}{*}{16.000} & \\
\hline Yes & 2 & 22 & & & 0 & 24 & & & 0 & 24 & & $<0.001$ \\
\hline TNM stage & & & & & & & & & & & & \\
\hline $\mathrm{I}+\mathrm{II}$ & 12 & 22 & 6588 & $0010^{*}$ & 10 & 24 & 5201 & $0023 *$ & 12 & 22 & & \\
\hline III+IV & 0 & 14 & 0.588 & 0.010 & 0 & 14 & 5.201 & 0.023 & 0 & 14 & 0.588 & 0.010 \\
\hline Lymph node met & & & & & & & & & & & & \\
\hline No & 12 & 18 & & & 10 & 20 & & & 12 & 18 & & \\
\hline Yes & 0 & 18 & 9.600 & $0.002^{2 n}$ & 0 & 18 & $1.5 / 9$ & $0.006^{n}$ & 0 & 18 & 9.600 & $0.002^{n}$ \\
\hline Differentiation $g$ & & & & & & & & & & & & \\
\hline High & 9 & 11 & & & 7 & 13 & & & 9 & 11 & & \\
\hline Middle & 3 & 20 & 7.687 & $0.021^{\star}$ & 3 & 20 & 4.596 & 0.100 & 3 & 20 & 7.687 & $0.021^{*}$ \\
\hline Low & 0 & 5 & & & 0 & 5 & & & 0 & 5 & & \\
\hline
\end{tabular}

The patients $(\mathrm{n}=48)$ were divided into either a low density $\left(<\mathrm{P}_{75}\right)$ group of high density $\left(\geq \mathrm{P}_{75}\right)$ group. ${ }^{*} \mathrm{p}<0.05,{ }^{* *} \mathrm{p}<0.01$ considered as statistically significant.

A

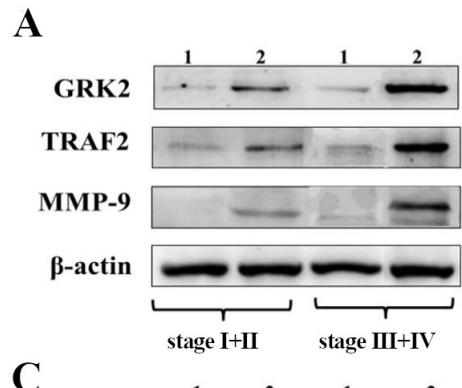

C

GRK2

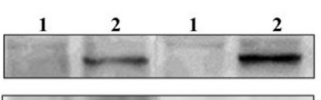

TRAF2

MMP-9

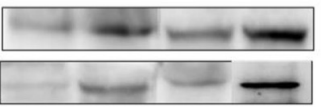

$\beta$-actin

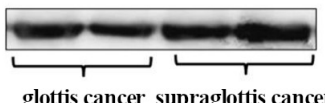

glottis cancer supraglottis cance stage I+II

E

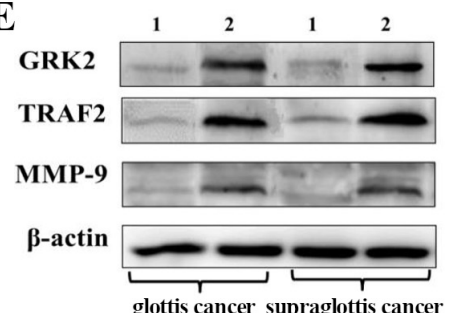

glottis cancer supraglottis cancer stage III+IV

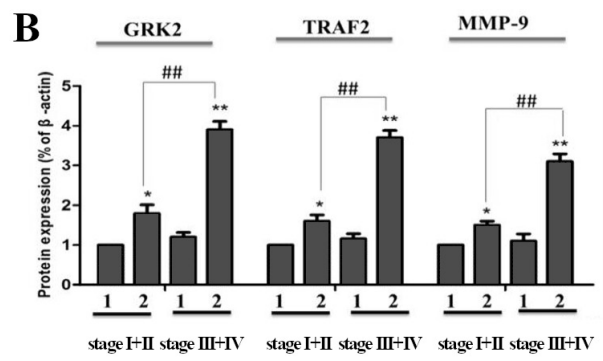

D

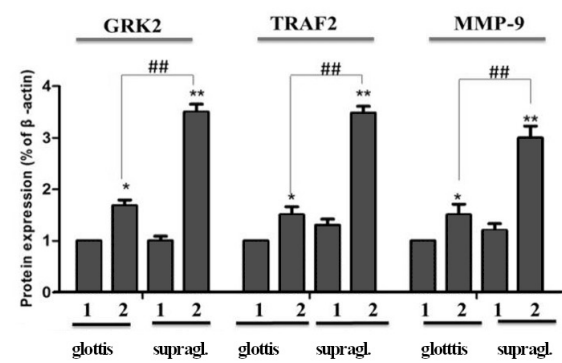

$\mathbf{F}$

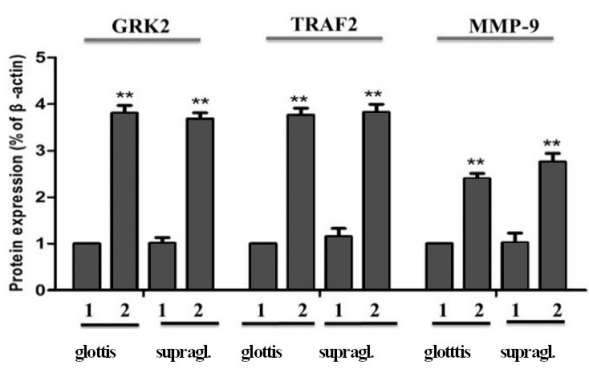

Figure 2. The expressions of GRK2/TRAF2/MMP9 were correlated with clinical stages and originated regions of LSCC. The early stages $(n=45)$ and the advanced stages $(n=17)$. A and B) GRK2, TRAF2 and MMP-9 expressions in early stages and advanced stages; C and D) GRK2, TRAF2 and MMP-9 expressions in glottic and supraglottic cancer tissues in early stages were detected by western blot; E and F) GRK2, TRAF2 and MMP9 expressions in glottic and supraglottic cancer tissues in advanced stages. Results are presented as mean \pm S.D. ${ }^{*} p<0.05$ versus tumor-adjacent tissues; ${ }^{* *} p<0.01$ versus tumor-adjacent tissues; $\# \# \mathbf{p}<0.01$ versus early stages LSCC tissues; 1 . tumor-adjacent tissues; 2 . LSCC tissues. 

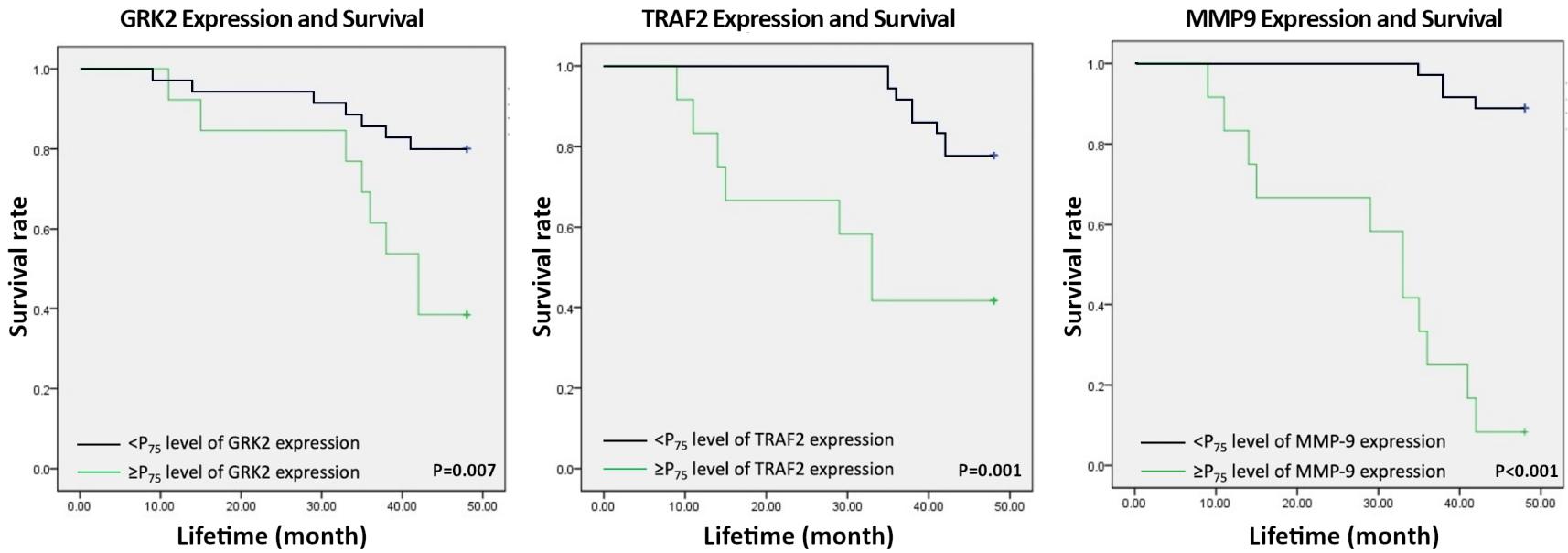

Figure 3. The expressions of GRK2, TRAF2 and MMP-9 correlate with the survival of LSCC patients Kaplan-Meier curves for the overall survival of LSCC patients, according to the expressions of $P_{75}$ of GRK2/TRAF2/MMP-9 immunostaining in LSCC tissues (n=48). The patients were divided into either a low density $\left(<\mathbf{P}_{75}\right)$ group of high density $\left(\geq \mathbf{P}_{75}\right)$ group. The survival status of each patients was obtained during 48 months of follow-up. Log rank $\mathbf{p}<\mathbf{0 . 0 1}$.

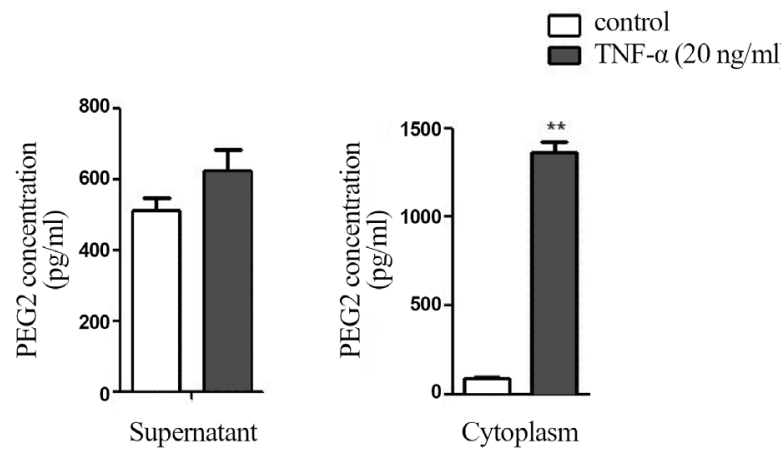

Figure 4. The levels of PGE2 in UM-SCC-11A cell cytoplasm and culture supernatant. The levels of PGE2 stimulated by TNF- $\alpha$ in UM-SCC-11A cell cytoplasm and culture supernatant were detected by ELISA $(n=4)$. Results are presented as mean \pm S.D. ${ }^{* *} \mathrm{p}<0.01$ versus TNF- $\alpha(20 \mathrm{ng} / \mathrm{ml})$.

both cellular supernatant and cytoplasm with stimulation of TNF-a. And we found that the PGE2 level in supernatant had no significant difference after stimulation by TNF- $\alpha$, while in the cytoplasm the PGE2 level was significantly increased after TNF- $\alpha$ stimulation (Figure 4), indicating that TNF- $\alpha$ stimulation increases PGE2 expression intracellularly. As the PGE2 level was not increased significantly in the extracellular fluid, the exogenous PGE2 is needed to stimulate UM-SCC-11A cells. First, we used TNF- $\alpha$ or PGE2 to stimulate UM-SCC-11A cells separately, and an enhanced proliferation, migration and invasion of UM-SCC-11A cells were observed. Then, we applied TNF- $\alpha$ and PGE2 to co-stimulate UM-SCC-11A cells, and we found that compared with the single stimulus of TNF- $\alpha$ or PGE2, the co-stimulation of TNF- $\alpha$ and PGE2 significantly promoted UM-SCC-11A cell proliferation, migration and invasion with statistical signifi- cance, indicating that TNF- $\alpha$ and PGE2 can synergistically promote LSCC tumor progression (Figures 5A, 5B, 5C).

PGE2 enhances TNF- $\alpha$ signaling by upregulating the association of GRK2 and TRAF2. In order to explore the mechanism of the synergic effect of PGE2 and TNF- $\alpha$, we first investigated the interaction of TRAF2 and GRK2 in both clinical samples and UM-SCC-11A cells. We found that TRAF2 and GRK2 were co-expressed in LSCC tumor tissue. In UM-SCC-11A cells, the interaction between TRAF2 and GRK2 was significantly increased after the co-stimulation of PGE2 and TNF- $\alpha$ compared with the control group (Figures 6A, 6B). Then we tested MMP-9 expression and the result showed that the expression of MMP-9 was increased in UM-SCC-11A cells co-stimulated by PGE2 and TNF- $\alpha$ compared with TNF- $\alpha$ single stimulus $(\mathrm{p}<0.05)$ (Figure $6 \mathrm{C})$. PKA inhibitor $\mathrm{H} 89$ was used to observe the phosphorylation of GRK2 (Ser685) in UM-SCC-11A cells before PGE2 stimulation. And we discovered that the p-GRK2(Ser685) was significantly increased after PGE2 stimulation, and when PKA was inhibited by H-89, the p-GRK2(Ser685) was significantly decreased $(\mathrm{p}<0.05)$, suggesting that $\mathrm{PGE} 2$ regulates GRK2 phosphorylation through PGE2/EPs/PKA pathway (Figure 6D). These results indicated that PGE2 enhances TNF- $\alpha$-TRAF2-MMP-9 signaling by upregulating the interaction between GRK2 and TRAF2 in LSCC tissues and in UM-SCC-11A cells (Figure 7).

\section{Discussion}

High levels of TNF- $\alpha$ and PGE2 play important roles in proliferation, migration and invasion of tumor cells [13-15]. Studies discovered that levels of PGE2, as well as TNF- $\alpha$, are increased in the early stages of LSCC [16-18]. These two pathways are activated simultaneously in the early stage, 
A
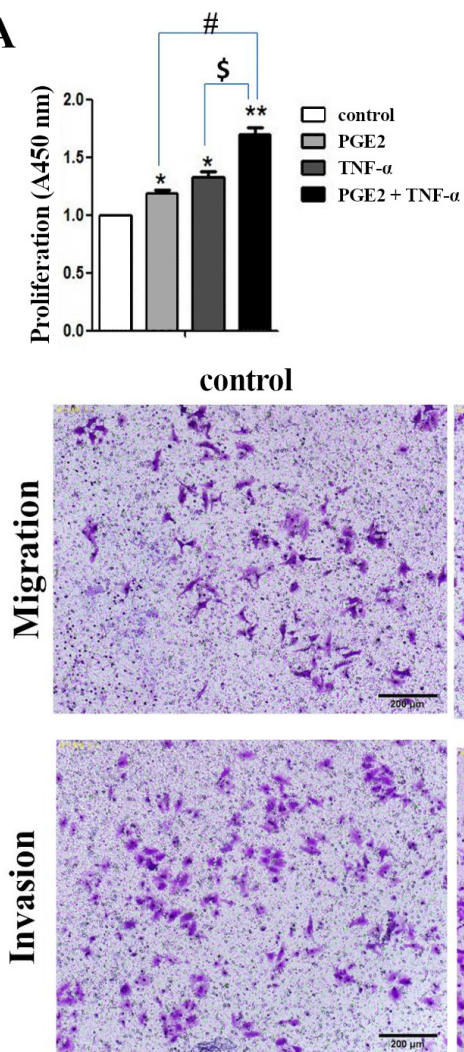

B

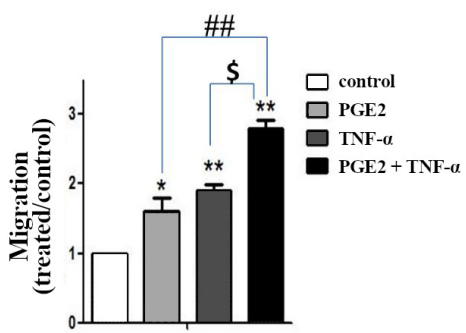

C

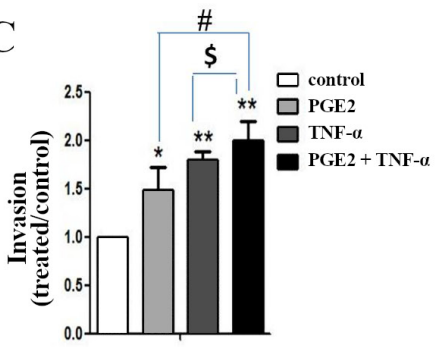

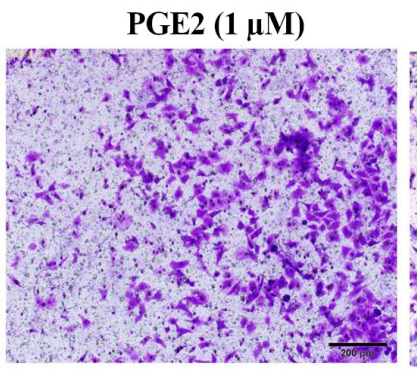

TNF- $(2)(20 \mathrm{ng} / \mathrm{ml})$

PGE2 $(1 \mu \mathrm{M})+\mathrm{TNF}-\alpha(20 \mathrm{ng} / \mathrm{ml})$
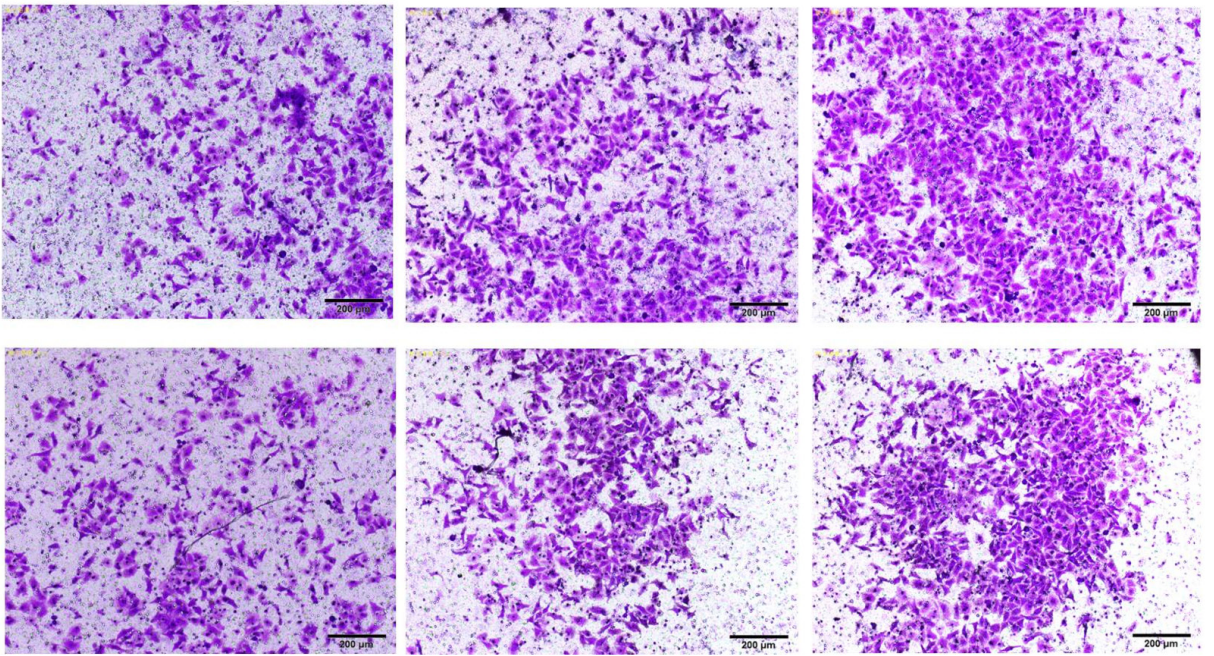

Figure 5. Both separate stimulation and co-stimulation of TNF- $\alpha$ and PGE2 can promote UM-SCC-11A cells proliferation, migration and invasion. A) Proliferation of UM-SCC-11A cells tested by CCK-8 assay $(n=4)$. B and C) Quantitative analysis of the UM-SCC-11A cells migration and invasion induced by PGE2 ( $1 \mu \mathrm{M})$ combined with TNF- $\alpha(20 \mathrm{ng} / \mathrm{ml})$; Representative images of the transwell assays (n=3) showing UM-SCC-11A cells migration and invasion (magnification $\times 100)$. Results are presented as mean $\pm S . D$. ${ }^{*} p<0.05$ versus control, ${ }^{* *} p<0.01$ versus control; \#p<0.05 versus $P G E 2(1 \mu M)$, \#\# $\mathbf{p}<0.01$ versus PGE2 $(1 \mu \mathrm{M}) ; \$ \mathrm{p}<0.05$ versus TNF- $\alpha(20 \mathrm{ng} / \mathrm{ml})$.

therefore, we assumed they may have a cross-talk. So we examined the levels of TNF- $\alpha$ and PGE2 in clinical samples. Our research found the levels of TNF- $\alpha$ and PGE2 were increased in LSCC tissue than in tumor-adjacent tissues in both early and advanced stages, indicating that TNF- $\alpha$ and PGE2 pathways may interact with each other with the progression of LSCC.

The previous studies reported that GRK2 was emerging as a potentially relevant onco-modulator and hallmark of cancer [19]. Changes in GRK2 levels could affect MAPK/ERK activation and cell proliferation in different ways depending on the cell types [20-22]. In addition, GRK2 targets the chemokine receptors CXCR4 and CXCR7, which are highly expressed in a range of tumors and contribute to the tumor metastasis $[23,24]$. Studies have shown that the upregulated GRK2 plays a driving role in basal breast cancer cells and leads to a reinforcement of EGF or heregulin-triggered mitogenic (ERK1/2) and survival (AKT) pathways $[25,26]$. Also, GRK2 is an important regulator of TNF-a signaling in myeloid cells both in vitro and in vivo [27]. The activation of TNF- $\alpha$ signaling pathway has been shown to mediate GRK2 facilitating TRAF2 translocation to the membrane in FLS.
In the previous studies, reports confirmed that the malignant tumors were involved in numerous interactions with the extracellular matrix (ECM), and matrix metalloproteinases (MMPs) may destroy ECM and assist the tumor cells invasion [28]. MMP-9 belongs to the subfamily of the MMPs and is secreted by leukocytes. It has been associated with the malignant phenotype of multiple tumor cells. Previous studies have shown that TNF- $\alpha$ upregulates MMP-9 expression. Except for the TRAF2-mediated MAPKs and NF- $\kappa$ B pathways [8], TNF- $\alpha$ may activate ERK, and stimulate AP-1 (activator protein-1), a well-described transcription factor, which promotes the transcription of MMP-9 and leads to the MMP-9 expression and cell invasion in MCF-7 cell [29]. Furthermore, TNF- $\alpha$ may activate FAK (focal adhesion kinase), increase the interference RNA and modulate the TNF- $\alpha$-FAK-ERK signaling cascade to increase the MMP-9 expression in human corneal epithelial cells [30]. Also, the expression of MMP-9 may positively correlate with the degree of malignancy of laryngeal cancer. Studies have shown that high expression of MMP-9 was related to the invasion and metastasis of laryngeal carcinoma in LSCC patients [31]. Meanwhile, in vitro silencing of the MMP-9 


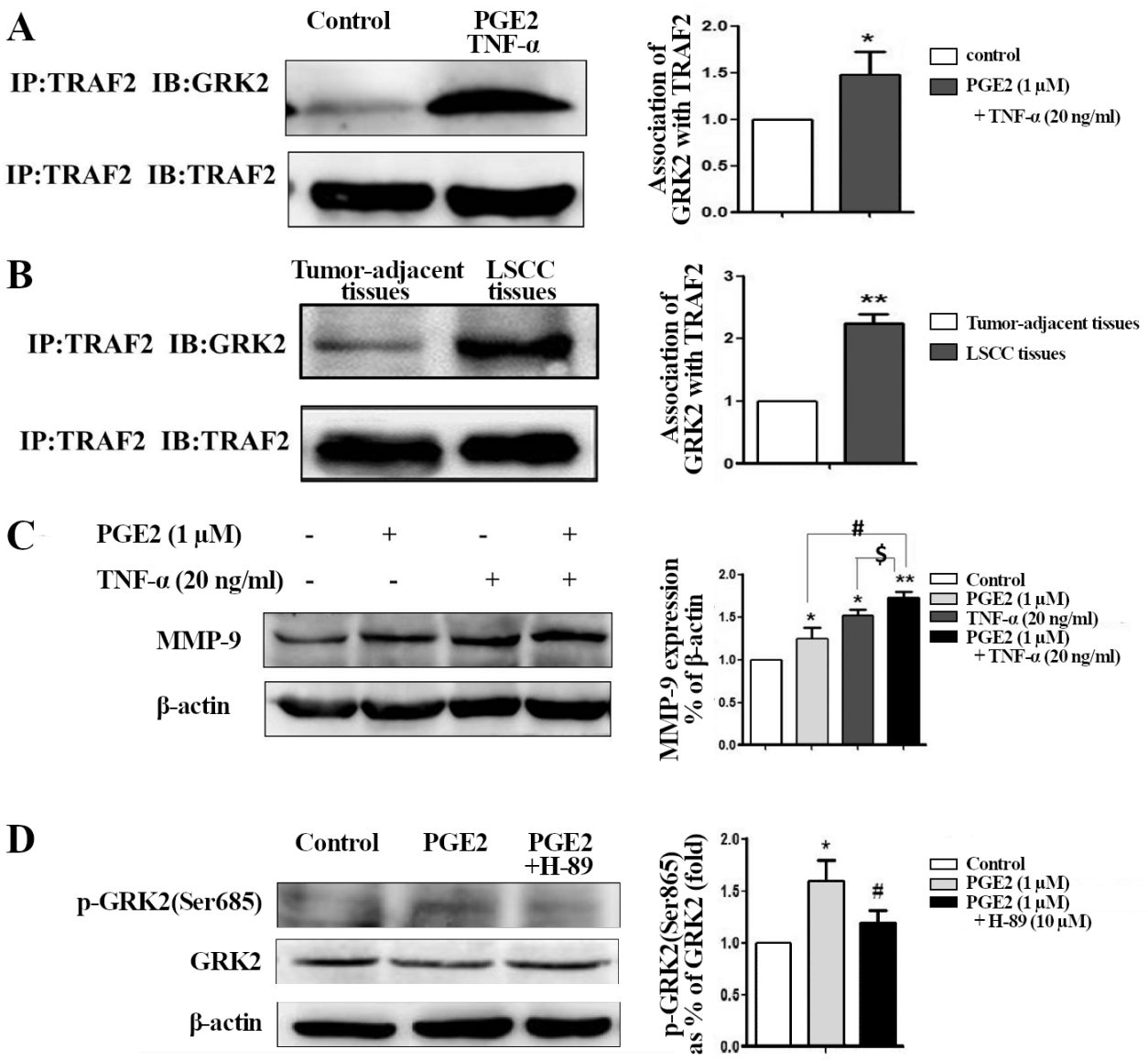

Figure 6. PGE2 enhances TNF- $\alpha$ signaling by upregulating the association of GRK2 and TRAF2. A and B) PGE2 (1 $\mu$ M) combined with TNF- $\alpha(20 \mathrm{ng} /$ $\mathrm{ml})$ promoted the interaction of GRK2 and TRAF2 in UM-SCC-11 A cells by Co-IP $(n=3)$; Compared with the tumor-adjacent tissues, the co-expression of GRK2 and TRAF2 was increased in LSCC tissues by Co-IP $(n=5)$; C) MMP-9 expression in UM-SCC-11A cells stimulated by PGE2 combined with TNF- $\alpha(n=3)$. D) The expression of p-GRK(Ser685) in UM-SCC-11A cells after PGE2 stimulation and PKA inhibitor H-89 inhibition. Results are presented as mean \pm S.D. ${ }^{\star} p<0.05$ versus control; ${ }^{* *} p<0.01$ versus control or tumor-adjacent tissues; $\# p<0.05$ versus $P G E 2(1 \mu M) ; \$ p<0.05$ versus TNF- $\alpha$ $(20 \mathrm{ng} / \mathrm{ml})$.

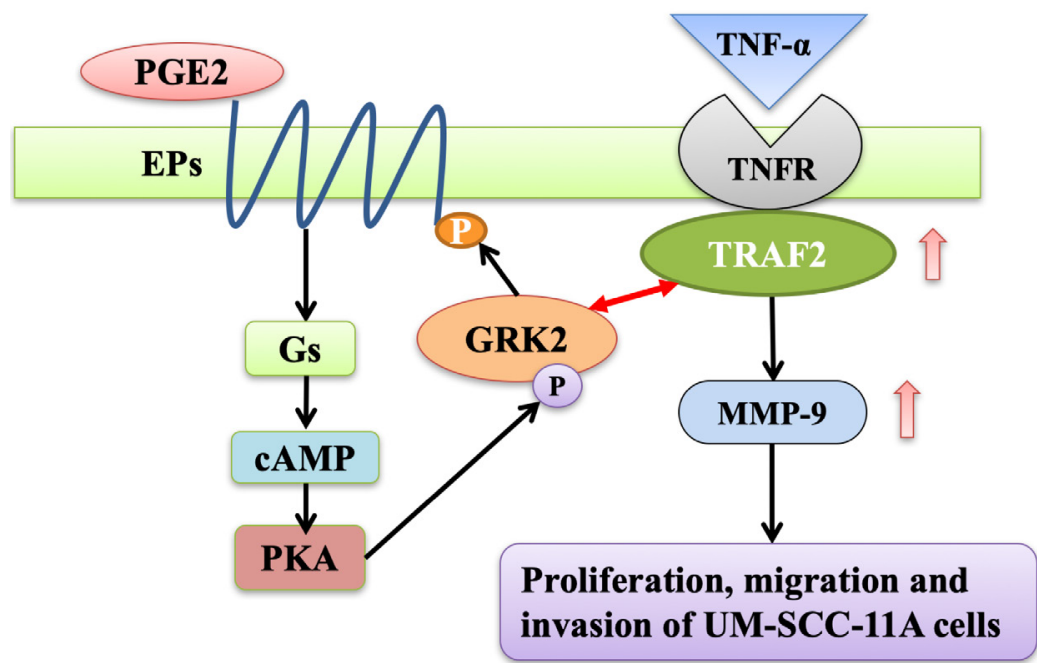

Figure 7. GRK2 and TRAF2 interaction can increase the TRAF2 expression. The interaction of GRK2 and TRAF2 may lead to the activation of TNF- $\alpha$-TRAF2-MMP-9 signaling, and increase the expression of MMP-9, which leads to the proliferation, migration and invasion of UM-SCC-11A cells. 
gene inhibits the invasion and proliferation of laryngeal cancer cells [32], indicating that MMP-9 is responsible for the progression of LSCC. Therefore, MMP-9 may become a predictor for the malignancy of the tumor and may indicate the prognosis of LSCC.

In this study, we tested the expressions of GRK2, TRAF2 and MMP-9 in clinical samples, and the results suggested that GRK2, TRAF2 and MMP-9 protein expressions in LSCC tissues were significantly increased than in tumor-adjacent tissues. Then we explored the relationship between clinicopathological characteristics of LSCC patients and GRK2, TRAF2 and MMP-9 protein expressions. The data suggest that tumor site, recurrence, lymph node metastasis, TNM stage and differentiation grade of the tumor are correlated with GRK2 and MMP-9 protein expressions. And tumor site, recurrence, lymph node metastasis and TNM stage were found significantly different with TRAF2 expression. The results showed that GRK2, TRAF2 and MMP-9 expressions may be involved in the progression and malignancy of LSCC. High expression of GRK2, TRAF2 and MMP-9 may lead to the poor outcomes of LSCC patients. Furthermore, we observed the expressions of GRK2, TRAF2 and MMP-9 in different stages of LSCC, the results showed the expressions of these three proteins were increased in all of the stage s of LSCC, and they were highly expressed in advanced stages than in early stages.

In addition, we analyzed the correlation between expressions of GRK2, TRAF2 and MMP-9 proteins and survival rate, and we discovered that survival rates of $\geq \mathrm{P}_{75}$ level were lower than that of $<\mathrm{P}_{75}$ level of GRK2, TRAF2 and MMP-9 expressions. These results revealed that the expressions of GRK2, TRAF2 and MMP-9 may be related to the clinical stages of LSCC, as well as survival time. And we selected the effective percentile values to reflect the correlation between GRK2, TRAF2 and MMP-9 expressions, which provides us a novel way to diagnose and predict the progression of LSCC.

The previous study has shown that TNF- $\alpha$ induces MMP-9 expression via TRAF2-mediated MAPKs and NF- $\kappa B$ activation [8]. Our results showed that TNF- $\alpha$ and PGE2 signaling pathways had cross-talked to each other, PGE2 enhanced TNF- $\alpha$-TRAF2-MMP-9 signaling by upregulating the interaction of TRAF2 and GRK2. Thus we assumed that the co-expression of TRAF2 and GRK2 may help to recruit and activate TRAF2. Therefore, the increase of TRAF2 may have positive effects on proliferation, migration and invasion of UM-SCC-11A cells and promote the expression of MMP-9.

In conclusion, TNF- $\alpha$ and PGE2 signaling pathways were activated and had a cross-talk in LSCC. GRK2, TRAF2 and MMP-9 expressions were related to the tumor site, recurrence, lymph node metastasis and TNM stage. Differentiation grade of tumor was found to be associated with GRK2 and MMP-9 expression. And GRK2, TRAF2 and MMP-9 expressions were associated with the survival time of LSCC. Additionally, TNF- $\alpha$ and PGE2 synergistically promoted the interaction of GRK2 and TRAF2, which lead to the activation of TRAF2 and its downstream molecular MMP-9, and promoted the proliferation, migration and invasion of UM-SCC-11A cells. Therefore, by illuminating the probable mechanism of GRK2 induced TRAF2 activation in LSCC, we provided a novel idea for the prevention and treatment of LSCC.

Acknowledgements: This research was supported by National Natural Science Foundation of China (No. 81330081; 81502123).

\section{References}

[1] SIEGEL RL, MILLER KD, JEMAL A. Cancer statistics, 2016. CA Cancer J Clin 2016; 66: 7-30. https://doi.org/10.3322/ caac. 21332

[2] WANG J, YANG S, GE W, WANG Y, HAN C et al. MiR-613 suppressed the laryngeal squamous cell carcinoma progression through regulating PDK1. J Cell Biochem 2018; 119: 5118-5125. https://doi.org/10.1002/jcb.26468

[3] JOO YH, PARK JO, CHO KJ, KIM MS. Relationship between paraglottic space invasion and cervical lymph node metastasis in patients undergoing supracricoid partial laryngectomy. Head Neck 2012; 34: 1119-1122. https://doi. org/10.1002/hed.21892

[4] LI L, WANG J, GAO L, GONG L. Expression of paxillin in laryngeal squamous cell carcinoma and its prognostic value. Int J Clin Exp Pathol 2015; 8: 9232-9239.

[5] AGGARWAL BB. Signalling pathways of the TNF superfamily: a double-edged sword. Nat Rev Immunol 2003; 3: 745756. https://doi.org/10.1038/nri1184

[6] WU J, GUO J, YANG Y, JIANG F, CHEN S et al. Tumor necrosis factor a accelerates Hep-2 cells proliferation by suppressing TRPP2 expression. Sci China Life Sci 2017; 60: 1251-1259. https://doi.org/10.1007/s11427-016-9030-5

[7] RAUERT H, STÜHMER T, BARGOU R, WAJANT H, SIEGMUND D. TNFR1 and TNFR2 regulate the extrinsic apoptotic pathway in myeloma cells by multiple mechanisms. Cell Death Dis 2011; 2: e194. https://doi.org/10.1038/ cddis. 2011.78

[8] TSAI CL, CHEN WC, HSIEH HL, CHI PL, HSIAO LD et al. TNF- $\alpha$ induces matrix metalloproteinase-9-dependent soluble intercellular adhesion molecule-1 release via TRAF2mediated MAPKs and NF- $\kappa \mathrm{B}$ activation in osteoblast-like MC3T3-E1 cells. J Biomed Sci 2014; 21: 12. https://doi. org/10.1186/1423-0127-21-12

[9] KIRKPATRICK A, BIDWELL J, VAN DEN BRULE AJ, MEIJER CJ, PAWADE J et al. TNF alpha polymorphism frequencies in HPV-associated cervical dysplasia. Gynecol Oncol 2004; 92: 675-679. https://doi.org/10.1016/j.ygyno.2003.11.025

[10] BIRRELL MA, MAHER SA, DEKKAK B, JONES V, WONG $S$ et al. Anti-inflammatory effects of PGE2 in the lung: role of the EP4 receptor subtype. Thorax 2015; 70: 740-747. https:// doi.org/10.1136/thoraxjnl-2014-206592 
[11] CONG M, PERRY SI, LIN FT, FRASER ID, HU LA et al. Regulation of membrane targeting of the $G$ protein-coupled receptor kinase 2 by protein kinase $\mathrm{A}$ and its anchoring protein AKAP79. J Biol Chem 2001; 276: 15192-15199. https:// doi.org/10.1074/jbc.M009130200

[12] LI X, HUSTON E, LYNCH MJ, HOUSLAY MD, BAILLIE GS. Phosphodiesterase- 4 influences the PKA phosphorylation status and membrane translocation of G-protein receptor kinase 2 (GRK2) in HEK-293beta2 cells and cardiac myocytes. Biochem J 2006; 394: 427-435. https://doi. org/10.1042/BJ20051560

[13] SHANG GS, LIU LX, QIN YW. IL6 and TNF- $\alpha$ promote metastasis of lung cancer by inducing epithelial-mesenchymal transition. Oncol Lett 2017; 13: 4657-4660. https://doi. org/10.3892/ol.2017.6048

[14] WILLIAMS AM, SHAH R, SHAYNE M, HUSTON A, KREBS $\mathrm{M}$ et al. Associations between inflammatory markers and cognitive function in breast cancer patients receiving chemotherapy. J Neuroimmunol 2018; 314: 17-23. https:// doi.org/10.1016/j.jneuroim.2017.10.005

[15] BASUDHAR D, GLYNN SA, GREER M, SOMASUNDARAM V, NO JH et al. Coexpression of NOS2 and COX2 accelerates tumor growth and reduces survival in estrogen receptor-negative breast cancer. Proc Natl Acad Sci U S A 2017; 114: 13030-13035. https://doi.org/10.1073/pnas.1709119114

[16] KAWATA R, HYO S, MAEDA T, URADE Y, TAKENAKA $\mathrm{H}$. Simultaneous expression of cyclooxygenase- 2 and microsomal prostaglandin E synthase in squamous cell carcinoma of the larynx. Acta Otolaryngol 2006; 126: 627-632. https:// doi.org/10.1080/00016480500452541

[17] STASKA K, FORMA E, BRYS M, GLOWACKA E, LEWYTRENDA I et al. The expression of TLR pathway molecules in peripheral blood mononuclear cells and their relationship with tumor invasion and cytokine secretion in laryngeal carcinoma. Adv Med Sci 2012; 57: 124-135. https://doi. org/10.2478/v10039-011-0058-3

[18] YASUKO N, WATARU K, SATOSHI S, HIROTO K, SOROKU Y. Expression of tumor necrosis factor- $\alpha$ and interleukin-6 in oral squamous cell carcinoma. Jpn J Cancer Res 1999; 90: 858-866. https://doi.org/10.1111/j.1349-7006.1999. tb00827.x

[19] RIVAS V, NOGUÉS L, REGLERO C, MAYOR F JR, PENELA P. Role of G protein-coupled receptor kinase 2 in tumoral angiogenesis. Mol Cell Oncol 2014; 1: e969166. https://doi.or $\mathrm{g} / 10.4161 / 23723548.2014 .969166$

[20] FILARDO EJ, QUINN JA, SABO E. Association of the membrane estrogen receptor, GPR30, with breast tumor metastasis and transactivation of the epidermal growth factor receptor. Steroids 2008; 73: 870-873. https://doi.org/10.1016/j. steroids.2007.12.025

[21] SOSA MS, LOPEZ-HABER C, YANG C, WANG H, LEMMON LA et al. Identification of the Rac-GEF P-Rex1 as an essential mediator of ErbB signaling in breast cancer. Mol Cell 2010; 40: 877-892. https://doi.org/10.1016/j.molcel.2010.11.029
[22] ROBINSON JD, PITCHER JA. G protein-coupled receptor kinase 2 (GRK2) is a Rho-activated scaffold protein for the ERK MAP kinase cascade. Cell Signal 2013 ; 25: 2831-2839. https://doi.org/10.1016/j.cellsig.2013.08.031

[23] O'HAYRE M, DEGESE MS, GUTKIND JS. Novel insights into $G$ protein and $G$ protein-coupled receptor signaling in cancer. Curr Opin Cell Biol 2014; 27: 126-135. https://doi. org/10.1016/j.ceb.2014.01.005

[24] LIPFERT J, ÖDEMIS V, ENGELE J. Grk2 is an essential regulator of CXCR7 signaling in astrocytes. Cell Mol Neurobiol 2013; 33: 111-118. https://doi.org/10.1007/s10571-0129876-5

[25] ZHANG F, XIANG S, CAO Y, LI M, MA Q et al. EIF3D promotes gallbladder cancer development by stabilizing GRK2 kinase and activating PI3K-AKT signaling pathway. Cell Death Dis 2017; 8: e2868. https://doi.org/10.1038/cddis. 2017.263

[26] LI W, JIA X, SHEN C, ZHANG M, XU J et al. A KSHV microRNA enhances viral latency and induces angiogenesis by targeting GRK2 to activate the CXCR2/AKT pathway. Oncotarget 2016; 7: 32286-32305. https://doi.org/10.18632/oncotarget.8591

[27] PATIAL S, LUO J, PORTER KJ, BENOVIC JL, PARAMESWARAN N. G-protein-coupled-receptor kinases mediate $\mathrm{TNF} \alpha$-induced NF- $\kappa \mathrm{B}$ signaling via direct interaction with and phosphorylation of IкBa. Biochem J 2009; 425: 169-178. https://doi.org/10.1042/BJ20090908

[28] BAI XY, LI S, WANG M, LI X, YANG Y et al. Krüppel-like factor 9 down-regulates matrix metalloproteinase 9 transcription and suppresses human breast cancer invasion. Cancer Lett 2018; 412: 224-235. https://doi.org/10.1016/j. canlet.2017.10.027

[29] JUNG YS, LEE SO. Apomorphine suppresses TNF- $\alpha$ induced MMP-9 expression and cell invasion through inhibition of ERK/AP1 signaling pathway in MCF-7 cells. Biochem Biophys Res Commun 2017; 487: 903-909. https://doi. org/10.1016/j.bbrc.2017.04.151

[30] YANG YN, WANG F, ZHOU W, WU ZQ, XING YQ. TNF- $\alpha$ stimulates MMP-2 and MMP-9 activities in human corneal epithelial cells via the activation of FAK/ERK signaling. Ophthalmic Res 2012; 48: 165-170. https://doi. org/10.1159/000338819

[31] GOU XX, CHEN HX, JIN F, WU WL, LI YY et al. Expressions CD147, MMP-2 and MMP-9 in laryngeal carcinoma and its correlation with poor prognosis. Pathol Oncol Res 2014; 20: 475-481. https://doi.org/10.1007/s12253-0139720-3

[32] Sun YN, Liu M, Yang BF, Lu JG, Li BX. Inhibition of laryngeal cancer cell invasion and growth with lentiviralvector delivered short hairpin RNA targeting human MMP-9 gene. Cancer Invest 2008; 26: 984-989. https://doi. org/10.1080/07357900802072897 